\title{
Penerapan Pendekatan Teknis untuk Meningkatkan Gerak Dasar Manipulatif dalam Pembelajaran Fielding Games Sederhana
}

\author{
Ayu Dwi Jayanti ${ }^{1}$, Andi Suntoda ${ }^{1}$, Didin Budiman ${ }^{1}$ \\ ${ }^{1}$ Program Studi Pendidikan Guru Sekolah Dasar Pendidikan Jasmani, Universitas Pendidikan Indonesia
}

\begin{abstract}
Info Artikel
SejarahArtikel:

Diterima Desember 2018

Disetujui April 2019

Dipublikasikan Mei 2019

Keywords:

Fielding Games, Gerak Dasar Manipulatif, Pendekatan Teknis

Abstrak

Penelitian ini bertujuan untuk mengetahui peningkatan gerak dasar manipulatif melalui penerapan pembelajaran field games sederhana kelas 4 sekolah dasar. Penelitian ini menggunakan metode penelitian tindakan kelas. Analisa data dilakukan dengan mereduksi data dan memaparkan data dalam bentuk tabel, sehingga dapat dicari nila rata-rata dan persentase ketuntasan belajar. Subjek dalam penelitian ini adalah siswa kelas IV Sekolah Dasar di Kota Bandung yang berjumlah 33 siswa. Terdiri dari 17 orang siswa putra dan 16 orang siswa putri. Hasil penelitian pada siklus I menunjukkan gerak dasar manipulatif siswa mencapai hasil (63,88\%), Pada siklus II menunjukkan bahwa gerak dasar manipulatif meningkat hingga mencapai $(80,55 \%)$. Penelitian ini menyimpulkan bahwa penerapan pendekatan teknis dapat meningkatkan gerak dasar manipulatif dalam pembelajaran field games sederhana.
\end{abstract}




\section{PENDAHULUAN}

Model pembelajaran mengacu pada pendekatan yang akan digunakan, termasuk didalamnya tujuan-tujuan pembelajaran, tahaptahap dalam kegiatan pembelajaran, lingkungan pembelajaran, dan pengelolaan kelas. Melalui model pembelajaran, guru dapat membantu peserta didik mendapatkan informasi, ide, keterampilan, cara berfikir, dan mengekspresikan ide. Model pembelajaran berfungsi pula sebagai pedoman bagi para perancang pembelajaran dan para guru dalam merencanakan aktivitas belajar mengajar.

Banyak model pembelajaran yang dapat digunakan agar memperoleh suatu ketangkasan dan keterampilan gerak pada siswa salah satunya adalah model pendekatan teknis. Pendekatan teknis adalah pendekatan latihan, atau pendekatan training yang merupakan suatu cara mengajar yang baik untuk menanamkan kebiasaan-kebiasaan tertentu. Juga sebagai sarana untuk memperoleh suatu ketangkasan, ketepatan, kesempatan, dan keterampilan (Sagala, 2009) .Menurut pendapat tersebut mengemukakan bahwa dengan penerapan pendekatan teknis dapat meningkatkan gerak dasar siswa karena ciri khas dari pendekatan ini adalah kegiatan berupa pengulangan berkali kali dari suatu hal yang sama. Dengan demikian terbentuklah sebuah keterampilan yang setiap saat siap untuk dipergunakan. Model pembelajaran mengacu pada pendekatan yang akan digunakan, termasuk di dalamnya tujuan-tujuan pembelajaran, tahap-tahap dalam kegiatan pembelajaran, lingkungan pembelajaran, dan pengelola kelas (Suherman, 2016).

Berdasarkan penjabaran tersebut, maka dapat disimpulkan bahwa model pembelajaran adalah suatu pola/rancangan yang dipilih/ digunakan selama kegiatan belajar. Dalam suatu model pembelajaran dapat digunakan untuk penyusunan kurikulum, pengaturan materi pembelajaran, dan menentukan langkahlangkah yang harus dilakukanoleh guru saat mengajar di kelas. Model pembelajaran yang dipilih dalam kegiatan belajar harus disesuaikan dengan materi yang akan dipelajari sehingga tujuan dari pembelajaran dapat tercapai

Model pembelajaran berarti seperangkat prosedur yang berurutan untuk melaksanakan pengembangan pembelajaran (Joyce, B., Weil, M., \& Calhoun, E., 1996). Model-model pembelajaran tersebut yaitu model pembelajaran langsung, model pembelajaran kooperatif, dan model pembelajaran berbasis masalah $\mathrm{Su}$ (Prijono, 2016). Model pembelajaran langsung atau direct instruction dikenal dengan sebutan active teaching atau dinamakan whole-class teaching. Model pembelajaran kooperatif merupakan model pembelajaran yang memiliki konsep yang lebih luas meliputi semua jenis keja kelompok termasuk bentuk-bentuk yang lebih dipimpim oleh guru atau diarahkan oleh guru. Sedangkan model pembelajran berbasis masalah dikembangkan berdasarkan konsep-konsep yang dicetuskan oleh Jerome Bruner. Konsep tersebut adalah belajar penemuan atau discovery learning.

Adapun karakteristik dari pendekatan teknis berkfokus pada keterampilan individual anak didik sendiri bukan hanya melihat dari segi umur atau level anak didik itu. Pendekatan teknik memiliki desain kurikulum dimana karakteristik kompetensi ialah pengembangan gerak lokomotor, nonlokomotor dan gerak manipulative. Termasuk mengembangkan pengalaman gerak dan instruksi gerak sesuai dengan apa yang dibutuhkan siswa dan disesuaikan 
dengan KD (Sucipto, 2015). Dari karakteristik diatas, mengaitkan penjas harus memberikan dampak positif bagi siswa agar mereka bisa menggunakan keterampilan yang mereka pelajari dari pendidikan jasmani di sekolah bisa menjadi bekal sepanjang hayatnya.

Sedangkan gambaran format pembelajaran pendekatan tradisional teknik formatnya adalah (1) pemanasan, (2) pengembangan keterampilan, (3) modifikasi permainan, dan (4) bermain (Sucipto, 2015). Dalam menerapkan pendekatan teknik dilakukan secara step-bystep yang diawali dengan peningkatan keterapilan, permainan sederhana, dan kepada permainan yang lebih kompleks yang menuntut kesadaran taktis dan juga dalam menerapkan pendekatan taktis dalam pembelajaran permainan formatnya diawali dengan pemanasan, pengembangan keterampilan, modifikasi permainan, dan kepada permainan yang sesungguhnya.

Berdasarkan uraian para ahli tersebut tujuan penelitian ini adalah untuk mengembangkan pembelajaran fielding games sederhana melalui penerapan pendekatan teknis untuk meningkatkan gerak dasar manipulatif.

\section{METODE PENELITIAN}

Jenis penelitian yang digunakan dalam penelitian ini adalah penelitian tindakan kelas (PTK). PTK adalah suatu kegiatan ilmiah yang berorientasi pada memecahkan masalahmasalah pembelajaran melalui tindakan yang disengaja dengan tujuan untuk memperbaiki dan meningkatkan proses dan hasil pembelajaran. Subjek dalam PTK ini adalah 54 siswa ke- las IV SDN Tilil Kota Bandung, yang terdiri dari 36 siswa perempuan dan 18 siswa laki-laki.

Dalam penelitian ini, peneliti menggunakan beberapa instrumen, diantaranya sebagai beriku: Lembar observasi, ini diadopsi dari (Oslin \& Mitchell, 2006) kemudian disesuaikan dangan variabel yang terkait dengan penelitian yang sedang dilakukan.

Dalam pelaksanaan tindakannya di SDN 032 Tilil Kota Bandung Kelas IV peneliti melakukan dua siklus yang terdiri dari siklus 1 , siklus 2 , dan siklus yang ditempuh sebagai berikut:

1. Pada siklus 1 tindakan 1 , proses pembelajaran dilakukan dengan memberikan penjelasan dan sosialisasi rinci tentang akan pentingnya kesehatan diri dalam upaya menjaga kesehatan dan memberi pemahaman tentang pentingnya model pembelajaran pendekatan teknis dalam permainan bola kasti untuk kepada siswa kelas IV SDN 032 Tilil Bandung.

2. Pada siklus 1 tindakan 2, proses pembelajaran dilakukan dengan memberikan penjelasan atau sosialisasi rinci tentang akan pentingnya kesehatan diri dalam upaya menjaga kesehatan dan memberi pemahaman tentang pentingnya pemahaman kesehatan diri untuk siswa agar selalu sehat serta membuat model pembelajaran tematik terpadu berformat pendekatan teknis di mana guru menyiapkan materi tentang pemahaman field games atau permainan bola kasti dengan menarik agar siswa dapat mengikuti serta bisa memahami penjelasan dari yang disampaikan oleh peneliti (guru). 
3. Pada siklus 2 tindakan 1, megulang kembali materi yang telah disampaikan sebelumnya yaitu penjelasan atau sosialisasi rinci tentang akan pentingnya kesehatan diri dalam upaya menjaga kesehatan dan memberi pemahaman tentang pentingnya pemahaman kesehatan diri untuk siswa agar selalu sehat serta membuat model pembelajaran tematik terpadu berformat pendekatan teknis di mana guru menyiapkan materi tentang pemahaman gerak dasar manipulatif dalam permainan bola kasti dengan menarik agar siswa dapat mengikuti serta bisa memahami penjelasan dari yang disampaikan oleh peneliti (guru).

4. Siklus 2 tidakan 2, memperbaiki kekurangan yang terdapat pada siklus 1 , sehingga kekurangan yang ada dapat di perbaiki pada siklus 2. Dengan cara ini siswa diberikan penjelasan mengenai pentingnya menjaga kesehatan diri dan memberi pemahaman tentang pentingnya pemahaman model pendekatan teknis meningkatkan gerak dasar dan nilai kerjasama dalam permainan bola kecil diri untuk siswa agar selalu sehat serta membuat model pembelajaran tematik terpadu berformat pendekatan teknis di mana guru menyiapkan materi tentang pemahaman gerak dasar manipulatif dalam permainan bola kasti diri dengan menarik agar siswa dapat mengikuti serta bisa memahami penjelasan dari yang disampaikan oleh peneliti (guru). Melalui tayangan video lalu mempraktikannya secara bersama-sama, lalu peneliti (guru) membuat kelompok belajar siswa dengan memilihnya sesuai dengan urutan absensi kelas, Hal ini dilakukan agar siswa mampu memecahkan permasalahan secara gerak manipulatif dengan rekan satu kelompoknya dan mendapatkan hasil yang baik.

Pada saat yang bersamaan kegiatan ini juga disertai dengan kegiatan observasi dan interpretasi serta diikuti dengan kegiatan refleksi dalam tes pelaksanaannya. Observasi ini dilaksanakan dengan tujuan untuk mengetahui hasil yang didapat pada pembelajaran tersebut peneliti membuat alat penelitian tentang pemahaman nilai kerjasama dan gerak dasar manipulatif yaitu lembaran kuesioner observasi atau dapat disebut lembar observasi.

\section{HASIL PENELITIAN}

Data keseluruhan merupakan gabungan yang dirata-ratakan dari hasil setiap tindakan, dan jika dibandingkan dengan data awal maka secara keseluruhan hasilnya mengalami peningkatan. Hal ini dapat dilihat pada diagram beri-

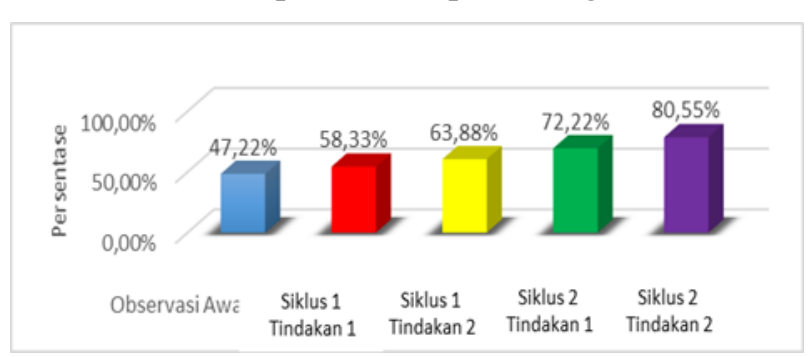

Gambar 1. Diagram Peningkatan Gerak Dasar dan Kerjasam Siswa dalam Permainan Bola Kecil

kut:

Dapat dilihat pada observasi awal hanya memperoleh persentase 47,22\%, kemudian dilanjutkan dengan siklus 1 tindakan 1 memperoleh persentase 58,33\% mengalami peningkatan di siklus 1 tindakan 2 memperoleh persentase $63,88 \%$ mengalami peningkatan $6,1 \%$. Memang pada siklus ini siswa tidak terlalu memahami pembelajaran tersebut, selanjutnya dari 
siklus 2 tindakan 1 memperoleh persentase $72,22 \%$ mengalami peningkatan dari siklus 1 tindakan 2 ke siklus 2 tindakan 1 sebesar 9\%. Selanjutnya dari siklus 2 tindakan 2 mendapatkan persentase $80,55 \%$ disini memperoleh hasil yang sangat memuaskan karena mengalami peningkatan dari siklus 2 tindakan 1 dengan selisih $9,1 \%$.

Berdasarkan hasil yang telah didapat selama proses penelitian ini, dan setelah penulis bertindak sebagai peneliti (guru yang melakukan kegiatan belajar mengajar) serta dibantu mitra peneliti (sebagai observer). Diskusi temuan dengan observer adalah sebagai berikut:

1. Pada awal pembelajaran siswa diberi tugas untuk membuat kelompok sama banyak, lalu tiap-tiap kelompok melakukan permainan bola kasti yang sederhana yang dipahami oleh mereka. Rata-rata dari setiap orang masih banyak yang belum mengerti tentang aktivitas permainan kasti.

2. Dalam pemberian tindakan kedua, siswa diberikan materi dan peraturan mengenai permainan kasti. Siswa banyak yang belum mengerti sehingga aktivitas pembelajarannya masih kurang optimal.

3. Setelah diberi beberapa perlakuan, pada tahap ini siswa yang dulunya belum memahami tentang permainan kasti sedikit demi sedikit siswa mulai terbiasa dan paham cara bermainnya.

4. Pada tahap selanjutnya siswa sudah mulai terbiasa, tetapi masih harus diberikan arahan tentang permainan kasti. Setiap siswa yang bermain melakukan permainan.
Upaya meningkatakan gerak manipulatif (memukul, melempar, dan menangkap) siswa melalui pembelajaran permaianan bola kasti pada siswa kelas IV di SD Negeri Tilil 032 Kota Bandung semula memang sulit diterapkan dan dipahami siswa. Hal tersebut disebabkan karena siswa malas bergerak dan tidak paham tentang cara permaianan bola kasti. Setelah diberikan arahan tentang permainan kasti siswa mulai memahami tugas gerak yang harus mereka lakukan. Mereka sangat bersemangat, senang, dan gembira ketika melakukan proses pembelajaran permainan gerak manipulatif (memukul, melempar, dan menangkap), dan keinginan untuk memenangkan permainan.

Dalam proses pembelajaran yang menggunakan permainan, siswa dibuat menjadi aktif dimaksudkan agar siswa merasa tidak bosan saat melakukan suatu aktivitas dengan memberikan mereka permainan, sehingga mereka bermain dengan senang hati dan tanpa disadari bahwa keterampilan geraknya terbina, kognitif dan afektifnya juga tercapai.

Dalam sebuah permainan ada satu permainan yang di teliti yaitu sebuah permainan kasti. Setelah melakukan beberapa tindakan atau perlakuan di lapangan selama penelitian, hal ini senjalan dengan hasil penelitian terdahulu mengemukakan bahwa pelaksanaan Permainan bola kasti berpengaruh terhadap teknik memukul dan berlari (Pertiwi, 2017) . Berdasarkan angket guru yang menjawab Ya hanya $80 \%$ dan Tidak hanya 20\%. Jadi Penerapan pelaksanaan permainan bola kasti dalam pembelajaran PJOK di SD Negeri Kota Bengkulu sudah terlaksana dengan baik." 


\section{KESIMPULAN}

Berdasarkan hasil penelitian yang dilakukan, penerapan pendekatan teknis dapat meningkatkan gerak dasar manipulatif dalam pembelajaran field games sederhanda. Melalui aktivitas permainan bola kasti siswa akan merasa lebih tertarik dan senang dalam pembelajaran pendidikan jasmani.

\section{DAFTAR PUSTAKA}

Joyce, B., Weil, M., \& Calhoun, E. (1996). Models of teaching Boston. MA: Allyn and Bacon.

Oslin, J., and Mitchell, S. (2006). Game-centred approaches to teaching physical education. In D. Kirk, D. Macdonald, \& M.

Pertiwi, T. S., \& Sutisyana, A. (2017). PELAKSANAAN PERMAINAN BOLA KASTI DALAM PEMBELAJARAN PENDIDIKAN JASMANI OLAHRAGA DAN KESEHATAN DI SD/MIN KOTA BENGKULU. KINESTETIK, 1(1).

Priyono, A. (2015). Pengembangan Model Pembelajaran Penjasorkes Melalui Permainan Cross Volley Ball Bagi Siswa Kelas V Sekolah Dasar Negeri Ketanon Sragi Kabupaten Pekalongan Tahun 2014 (Doctoral dissertation, UNIVERSITAS NEGERI SEMARANG).

Sagala, Syaiful. (2009). Konsep dan Makna Pembelajaran. Bandung: CV

Sucipto, (2015). Pembelajaran Permainan Futsal (Implementasi Pendekatan Taktis). Bandung

Suherman, A. (2016). Pengaruh Penerapan Model Kooperatif Tipe Jigsaw Dan Tgt (Teams Game Tournament) Terhadap Keterampilan Sosial Dan Keterampilan Bermain Bolavoli. JURNAL PENDIDIKAN JASMANI DAN OLAHRAGA, 1(2), 8-15. 